\title{
THE THEORETICAL ANALYSIS OF MASS AND ENERGY FLOW THROUGH SOLAR COLLECTOR - CHIMNEY SYSTEM
}

\author{
Zygmunt LIPNICKI ${ }^{1}$, Marta GORTYCH, Anna STASZCZUK, \\ Tadeusz KUCZYŃSKI \\ University of Zielona Gora, Zielona Góra, Poland
}

\begin{abstract}
The goal of the paper was to simplify the designing process for mass and energy flow through solar collector - chimney system. Theoretical analysis allowed to get involved system of three nonlinear analytical equations in dimensionless forms that have been saved. Dimensionless numbers for the problem are well known in the literature on fluid mechanics and thermodynamics: Reynolds, Grashof, Galileo, Biot and Prandtl. In the analyzed equations are also dimensionless geometric parameters expressing the ratios of basic geometrical dimensions of the collector system-chimney: the radius disc collector to the thickness gap, the height and radius of the chimney. In the system of equations, the Reynolds number is treated as the determined number, which is a novelty of the method used.
\end{abstract}

Keywords: solar collector - chimney system, air flow, analytical solution.

\section{INTRODUCTION}

The air flow and associated heat transfer through solar collector - chimney system became an important topic of many research projects. Depending on the research directions, it may serve various goals, from evaluating the effect of parameters of the systems air flow by natural ventilation in the buildings through small-scale systems of electrical energy generation to its generation in

1 Corresponding author: University of Zielona Gora, Faculty of Civil and Environmental Engineering, Z. Szafrana st 1, 65-516 Zielona Góra, Poland, e-mail: z.lipnicki@iis.uz.zgora.pl, m.gawron@iis.uz.zgora.pl, a.staszczuk@ib.uz.zgora.pl,t.kuczynski@iis.uz.zgora.pl 
full-scale systems. Many papers were published on the subject, mainly devoted to the analysis of concrete experimental projects which do not have sufficient theoretical analysis. In the existing scientific literature there is lack of simple analytical analysis of the air flow and associated heat transfer through solar collector - chimney systems. The theory is usually used to illustrate and analyze real systems than attempt to provide the simple analytical model to connected dynamics of air movement and heat transfer in the solar collector - chimney system.

Solar collector - chimney system can work as a solar thermal power plant, which firstly converts solar energy into thermal energy in the solar collector to farther convert it into kinetic energy in the chimney which final electricity generation by applying the wind turbine and generator.

One of the first attempts to use the solar collector systems and a chimney is the one proposed in 1903 by Isidoro Cabanyes. His work - engine design proposed the introduction of solar air heater attached to the house with chimney. The interior of the chimney was equipped with some type of rotor to produce electricity [4]. For the first time a joined system of solar collector and the chimney was designed by Schlaich in 1970 in Manzanares, Spain. Chimney height was $195 \mathrm{~m}$, its diameter $10 \mathrm{~m}$ with collector radius $122 \mathrm{~m}$. The prototype has been recognized as an experimental model on a small scale. Its final power was about $50 \mathrm{~kW}$ [7]. Schlaich, 1995 proposed a new approach for designing a solar collector chimney, in which the collector uses both direct and diffuse radiation and heat storage provided by soil. The construction of the solar collector and the chimney uses simple materials and technologies [13].

Considering the fact that solar chimney systems are a large role in energy supply in countries where there is abundant sunlight. Many researchers have studied this type of technology, especially in the last few decades, they have studied the production technology of thermal solar energy which is the potential applications worldwide. Gannon and Von Backstrom in 2002 proposed the use of a mathematical model of the rotor system for energy production in solar chimney systems. As show research to improve the efficiency occurs when the applied inlet guide vanes [6], in another study examined the different crosssections along the model of a turbine blade rotors with different numbers [5]. Bernardes et al., 2003 developed a comprehensive analysis of the analytical and numerical models describing the operation of the solar collector chimney, that allow to estimate the power of solar chimneys, as well as to investigate the influence of different environmental conditions and geometrical dimensions on the power of solar chimneys. The mathematical model was validated with experimental results and was used to predict the performance characteristics of large-scale commercial solar chimneys. It turned out that the stack height, 
pressure drop rate in the turbine, and diameter properties are all of high importance [3].

Maia et al., 2009 analyzed the turbulent flow inside a solar chimney. Turbulent flow was modeled by the numerical solution - equation of mass, energy, and momentum. The experimental results were compared to analytical ones. They observed that the most important physical variables in a solar chimney project refer to tower dimensions. The model of the airflow proposed allows to determine the fields of velocity an temperature inside the solar chimney [9]. Tayebi and Djezzar, 2013 analyzed the thermo-hydrodynamic conditions for the air flow in natural convection conditions. Laminar steady quasi-state flow is presented in the system for established of boundary conditions. The method and fluid flow in the system were tested for two different geometries. Simulations were performed based on three values of Rayleigh number, $\mathrm{Ra}=103,104$ and 105. The results indicate that the maximum speed at the inlet of the tower and chimney. The results of this work will allow the designer to properly locate the solar chimneys turbine [15].

Asnaghi and Ladjevardi in 2012, studied the effectiveness of solar chimney power plant in Iran. The results showed that the solar chimney system having the same dimensions as in Manzanares can produce from 10 to $28 \mathrm{MWh} /$ month electricity [1]. Evaluates different environmental conditions and dimensions of the solar chimney in Iran [12]. It has been shown that the solar chimney power plant with a height of $350 \mathrm{~m}$ and a diameter of $1000 \mathrm{~m}$ collector can produce a monthly average of 1-2 MW of electricity air flow inside the chimney solar power plant are described in the work of Bernoulli's equation Hamdan 2013 [8]. Park et al. analyzed typical renewable energy systems for energy and exergy Maia et al., describe their analysis of the air flow inside the plant with the use solar chimney the experimental data [11] and [10].

There are studies based on the review on renewable energy particular solar chimney. Zhou et al. in 2010, presented the image of the research and development of solar chimney power plants in the past few years [17]. Chew and Shi presented an overview of the design on renewable energy systems, in particular, a system based on solar energy [14]. Zhai et al. provides an overview of the main configuration and integrated renewable energy systems based on solar chimneys. The results showed that solar chimney technology has been recognized as an effective and economical way to design a low-carbon buildings [16]. Banos et al. in 2011 provides an overview of the current state of knowledge in the calculation optimization methods used for renewable and sustainable energy [2].

The aim of the work is to create an analytical approach and based on it simple calculation method for solar collector-chimney systems which can generate electricity. 


\section{THE THEORETICAL MODEL OF THE SYSTEM}

The theoretical model of solar collector - chimney system is shown in Figure 1.

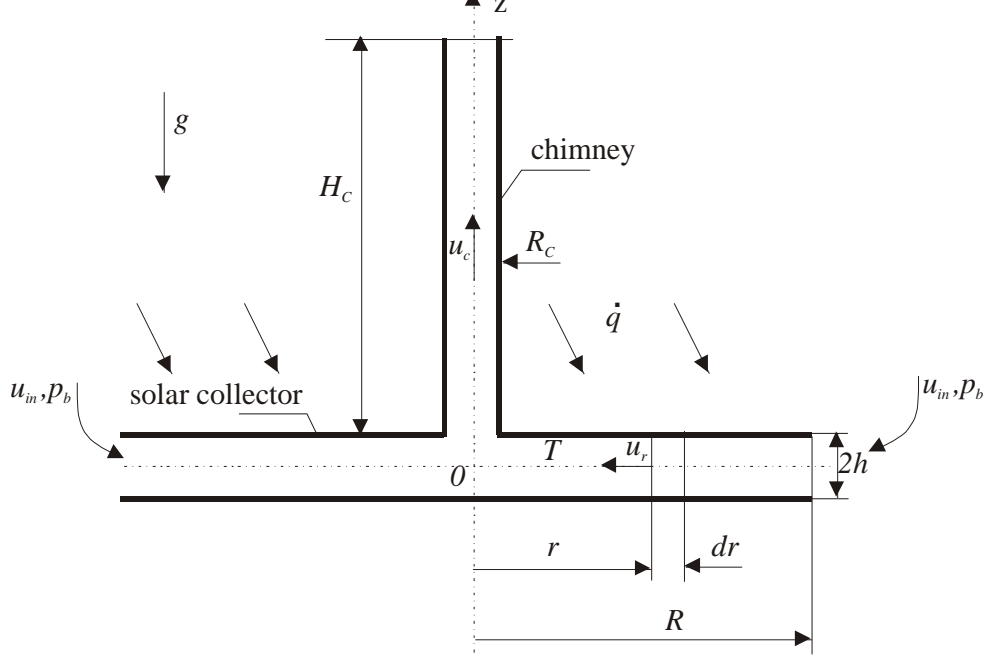

Fig. 1. Solar collector - chimney system

The radius and the height of the tower are respectively $R_{C}$ and $H_{C}$. Cover height of the solar collector is constant $2 h$, the solar collector radius is $R$. The absorbed solar radiation by the air flow is $\dot{q}$. Velocity and pressure of the air entering to the solar collector are respectively $u_{i n}$, and $p_{b}$, the velocity of the air in chimney is $u_{c}$. The air temperature inside collector is $T$.

\subsection{The analysis of the incompressible flow of Newtonian fluids in the solar collector}

Taking the incompressible flow assumption into account and assuming constant viscosity inside the collector (see Fig. 1), the Navier-Stokes equation will read, in form:

$$
f_{r}-\frac{1}{\rho} \frac{\partial p}{\partial r}=\frac{\partial u_{r}}{\partial t}+u_{r} \frac{\partial u_{r}}{\partial r}-v\left[\frac{1}{r} \frac{\partial}{\partial r}\left(r \frac{\partial u_{r}}{\partial r}\right)-\frac{u_{r}}{r^{2}}+\frac{\partial^{2} u_{r}}{\partial z^{2}}\right]
$$

From the principle of conversation of mass the total mass flux crossing the cylindrical surface is

$$
u_{r} r=\text { const. } \Rightarrow u_{r}+r \frac{\partial u_{r}}{\partial r}=0 \Rightarrow r \frac{\partial u_{r}}{\partial r}=-u_{r} .
$$


Equation (2.1) can be reduced as follows, after introducing the above equation and assuming the stationary flow $\partial u_{r} / \partial t=0$ and lack of the mass force $f_{r}=0$.

$$
-\frac{1}{\rho} \frac{\partial p}{\partial r}=\frac{1}{2} \frac{\partial u_{r}^{2}}{\partial r}-v \frac{\partial^{2} u_{r}}{\partial z^{2}}
$$

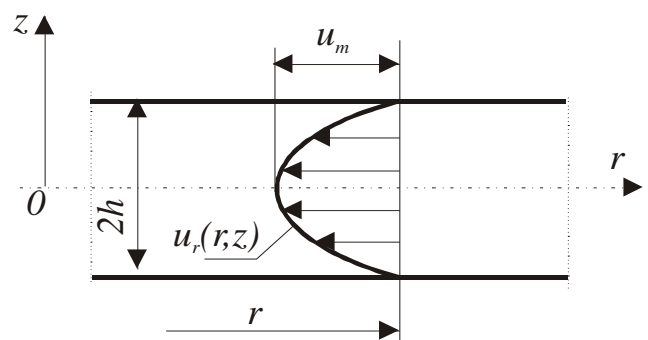

Fig. 2. Velocity profile in the collector channel

The velocity and the derivative of the velocity in any cross-section can be described by equations (see Fig. 2)

$$
u_{r}(r, z)=-u_{m} \cdot\left(1-\frac{z^{2}}{h^{2}}\right) \Rightarrow \frac{\partial u_{r}(r, z)}{\partial z}=u_{m} \cdot 2 \cdot \frac{z}{h^{2}} \Rightarrow \frac{\partial^{2} u_{r}(r, z)}{\partial z^{2}}=2 \frac{u_{m}}{h^{2}},
$$

where $u_{m}$ is the maximum velocity in any cross section $r$ and $2 h$ is the distance between the blades.

The maximum velocity as a function of the average velocity is determined on the basis of the analysis

$$
\bar{u}_{r}=\frac{\int_{-h}^{h} u_{m}\left(1-\frac{z^{2}}{h^{2}}\right) d z}{2 h}=\frac{2}{3} u_{m} \Rightarrow u_{m}=\frac{3}{2} \bar{u}_{r} .
$$

By substituting the above relation in the equation (2.3) and use the simplification the simple differential equation is obtained

$$
-\frac{1}{\rho} \frac{\partial p}{\partial r}=\frac{6}{5} \frac{\partial \bar{u}_{r}^{2}}{\partial r}-3 v \frac{\bar{u}_{r}}{h^{2}} .
$$

After separation of variables and integrating, and using the mass conservation law $u_{i n} R=\bar{u}_{r} r$ ( $u_{i n}$ - the air velocity at the inlet to the collector) the equation can be written 


$$
-\frac{p}{\rho}=\frac{u_{i n}^{2} R^{2}}{2 r^{2}}-\frac{3 v R u_{i n}}{h^{2}} \int \frac{d r}{r}+C,
$$

where $C$ is a constant.

The above equation fulfill the boundary condition

$$
p=p_{b} \text { for } r=R .
$$

An under-pressure of the flow air inside the collector as a function of the radius, by integration of the equation (2.7) and calculation of the constant $C$, can be expressed as

$$
p_{b}-p=\frac{1}{2} \rho u_{i n}^{2}\left[\left(\frac{R}{r}\right)^{2}-1\right]+\frac{3 v \rho R u_{i n}}{h^{2}} \ln \frac{R}{r} .
$$

Hereby we introduce the following dimensionless variables

$$
\tilde{r}=\frac{r}{R} ; \Pi=\frac{2\left(p_{b}-p\right)}{\rho u_{o}^{2}} ; \operatorname{Re}=\frac{u_{i n} h}{v} ; n=\frac{h}{R} .
$$

Equation (2.9) can be reduced as follows, after introducing non-dimensional quantities

$$
\Pi=\frac{6}{5}\left(\frac{1}{\tilde{r}^{2}}-1\right)+\frac{6}{n \operatorname{Re}} \ln \left(\frac{1}{\tilde{r}}\right)
$$

The shapes of the under-pressure and the velocity in the collector are given in Figure 2.

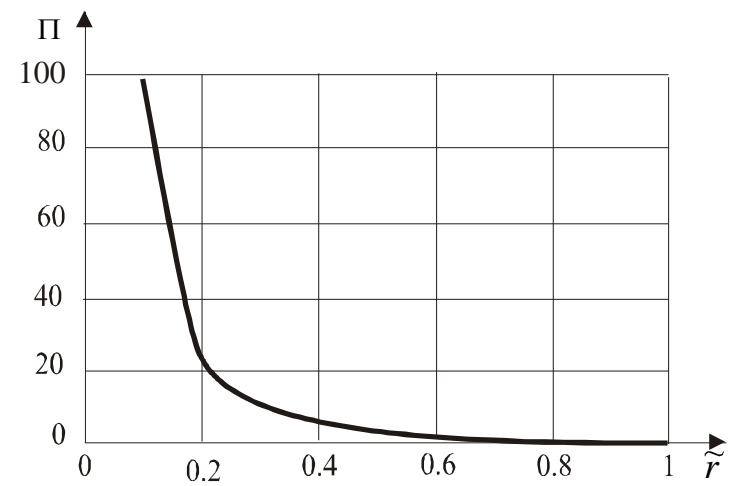

Fig. 3. Distribution of dimensionless pressure $\Pi$ for $\operatorname{Re}>500, n=0.05$ 
From the Figure 3 we can see that the dimensionless pressure $\Pi$ depends only on the radius $\tilde{r}$. From the theoretical point of view in the center of the collector the dimensionless pressure is equal the infinity. From practical point of view the radius of chimney has the finite value, so the press parameter is also finite.

\subsection{The dynamics of heat exchange supported air flow}

The instantaneous heat $\dot{q}$ from the sun is transferred to the air which flows between the circular plates. The energy balance may be described by equation:

$$
\begin{aligned}
& \dot{q} \cdot 2 \pi \cdot r \cdot d r-2 \pi \cdot r \cdot d r \cdot \alpha\left(T-T_{o t}\right)= \\
& 2 h \cdot \rho \cdot c_{p} \cdot 2 \pi \cdot r \cdot T \cdot \bar{u}_{r}-2 h \cdot \rho \cdot c_{p} \cdot 2 \pi(r+d r) \cdot\left(\bar{u}_{r}+d \bar{u}_{r}\right) \cdot(T+d T)
\end{aligned}
$$

After the rejection of the higher-order small parameters in the above equation we obtain:

$$
\dot{q} \cdot 2 \pi \cdot r \cdot d r-2 \pi \cdot r \cdot d r \cdot \alpha\left(T-T_{o t}\right)=-2 h \cdot \rho \cdot c_{p} \cdot 2 \pi \cdot d\left(r \cdot \bar{u}_{r} \cdot T\right) .
$$

Thanks the principle of conversation of mass ( $r \bar{u}_{r}=$ const. ) the above equation (2.12) can be written

$$
\dot{q} \cdot r \cdot d r-r \cdot d r \cdot \alpha\left(T-T_{o t}\right)=-2 h \cdot \rho \cdot c_{p} \cdot u_{i n} \cdot R \cdot d T .
$$

After separation of variables to give the equation

$$
r \cdot d r=\frac{2 h \cdot R \cdot \rho \cdot c_{p} \cdot u_{i n}}{\alpha} \frac{d\left[\dot{q}-\alpha\left(T-T_{o t}\right)\right]}{\dot{q}-\alpha\left(T-T_{o t}\right)},
$$

the solution to this equation is

$$
\frac{r^{2}}{2}=\frac{2 h \cdot R \cdot \rho \cdot c_{p} \cdot u_{i n \cdot}}{\alpha} \ln \left[\dot{q}-\alpha\left(T-T_{o t}\right)\right]+\ln C,
$$

where $C$ is constant.

The boundary condition gives

$$
r=R, \quad T=T_{o t} .
$$

Thus by substitution in (2.15), these steady state temperature distribution can be expressed by the following equation 


$$
T=T_{o t}+\frac{\dot{q}}{\alpha}\left[1-\exp \left(-\frac{\alpha}{4 h \cdot R \cdot \rho \cdot c_{p} \cdot u_{i n}}\left(R^{2}-r^{2}\right)\right)\right] .
$$

By introducing the following dimensionless variables:

$$
\begin{aligned}
& \tilde{r}=\frac{r}{R} ; \quad \theta=\frac{T-T_{o t}}{T_{\text {ot }}} ; \quad \tilde{\dot{q}}=\frac{\dot{q}}{\alpha T_{\text {ot }}} ; \quad B i=\frac{\alpha h}{\lambda_{s}} ; \quad \tilde{\lambda}=\frac{\lambda_{s}}{\lambda} ; \\
& \operatorname{Re}=\frac{u_{\text {in }} h}{v} ; \quad \operatorname{Pr}=\frac{v}{a} ; \quad n=\frac{h}{R}
\end{aligned}
$$

equation (2.17) can be reduced as follows:

$$
\theta=\tilde{\dot{q}}\left\{1-\exp \left[-\frac{B i \tilde{\lambda}}{4 n \operatorname{Re} \operatorname{Pr}}\left(1-\tilde{r}^{2}\right)\right]\right\}
$$

The curve of the temperature distribution in the collector depending on the radius of the collector is presented on Figure 4.

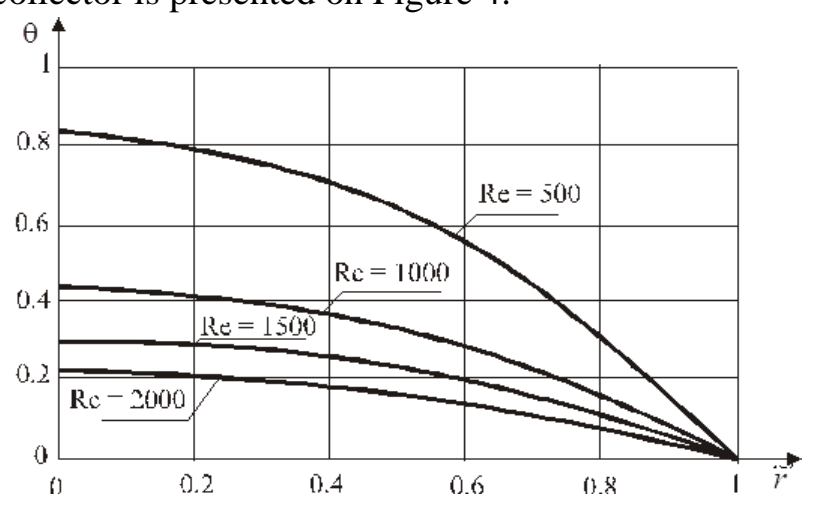

Fig. 4. Distribution of temperature inside collector for $\mathrm{Bi}=15, \mathrm{n}=0.05, \operatorname{Pr}=0.712$,

$$
\tilde{\dot{q}}=4.735
$$

\subsection{The analysis of the incompressible flow in the chimney}

The momentum equation of flow inside the chimney (see Fig. 1), can be written in form:

$$
0=-\frac{1}{\rho} \frac{\partial p_{c}}{\partial z}-g+v\left[\frac{1}{r} \frac{\partial}{\partial r}\left(r \frac{\partial u_{c}}{\partial r}\right)\right]
$$


The above equation can be rewritten in the form of two independent equations which equal the common constant (2.20)

$$
v\left[\frac{1}{r} \frac{\partial}{\partial r}\left(r \frac{\partial u_{c}}{\partial r}\right)\right]=\frac{1}{\rho_{c}} \frac{\partial p_{c}}{\partial z}+g=\text { const. }
$$

As can be seen the left side of the equation (2.20) depends on $r$, the right side depends on $z$. This implicates that both sides are equal to a common constant. Integrating the second of the above equation and applying the boundary conditions:

$$
\text { for } z=0, p_{c}=p_{C 0} \text { and for } z=H_{C}, p_{c}=p_{H} \text {, }
$$

the pressure distribution in the chimney and the value of the constant are equal respectively:

$$
\begin{gathered}
p_{c}=p_{C 0}+\left(\frac{p_{b}-p_{c 0}}{\rho_{c} H_{c}}-\frac{\rho}{\rho_{c}} g\right) \rho_{c} z, \\
\text { const }=\frac{p_{b}-p_{c 0}}{\rho H_{c}}+\left(\frac{p_{b}-p_{c 0}}{\rho H_{c}}-g\right) \beta\left(T_{0}-T_{o t}\right),
\end{gathered}
$$

the following correlations were used in the above equations:

$$
p_{H}=p_{b}-\rho g H_{c}, \rho_{c}=\rho\left[1-\beta\left(T_{0}-T_{o t}\right)\right] .
$$

Integrating the first equation (2.20) and using the boundary conditions inside the chimney for $r=R_{C}, u_{c}=0$ and for $r=0, u_{c}<\infty$, the velocity in the chimney is obtained as:

$$
u_{c}=\left\{-\frac{p_{b}-p_{c 0}}{4 v \rho H_{c}}-\left(\frac{p_{b}-p_{c 0}}{4 v \rho H_{c}}-\frac{g}{4 v}\right) \beta\left(T_{0}-T_{o t}\right)\right\}\left(R_{C}{ }^{2}-r^{2}\right),
$$

and in dimensionless form

$$
\tilde{u}_{c}=\left\{-\frac{\Pi_{C} \operatorname{Re}}{8 n m}-\left(\frac{\Pi_{C} \operatorname{Re}}{8 n m}-\frac{n G a}{4 \operatorname{Re}}\right) \frac{G r_{o}}{G a} \theta_{0}\right\}\left(\tilde{r}_{C}^{2}-\tilde{r}^{2}\right),
$$

where the velocity in the chimney, the press parameter in the beginning of chimney, the Reynolds number, the Galilei number, the Grashof number, and two geometric parameters of the collector-chimney system can be presented respectively as: 


$$
\begin{aligned}
& \tilde{u}_{C}=\frac{u_{C}}{u_{i n}} ; \quad \Pi_{C}=\frac{2\left(p_{b}-p_{C O}\right)}{\rho u_{O}^{2}} ; R e=\frac{u_{i n} h}{v} ; G a=\frac{g R^{3}}{v^{2}} \quad G r_{O}=\frac{g \beta T_{O t} R^{3}}{v^{2}} ; \\
& n=\frac{h}{R} ; m=\frac{H_{C}}{R} .
\end{aligned}
$$

The average velocity in the chimney is

$$
\tilde{\bar{u}}_{c}=\frac{1}{2}\left\{-\frac{\Pi_{C} \operatorname{Re}}{8 n m}-\left(\frac{\Pi_{C} \operatorname{Re}}{8 n m}-\frac{n G a}{4 \operatorname{Re}}\right) \frac{G r_{o}}{G a} \theta_{0}\right\} \tilde{r}_{C}^{2} .
$$

From the mass conservation principle in the solar collector - chimney system we have

$$
\rho_{C} \bar{u}_{C} \pi R_{C}^{2}=\rho u_{i n} 4 \pi n R^{2} \Rightarrow \bar{u}_{C}=4 u_{i n} n \rho_{C} / \rho \tilde{r}_{C}^{2} .
$$

The condition for the air flow in the chimney is

$$
G r_{0} \theta_{0}>\frac{\Pi_{C} \operatorname{Re}^{2}}{2 n^{2} m}+\frac{\Pi_{C} \operatorname{Re}^{2} G r_{0}}{2 n^{2} m G a} \theta_{0} .
$$

From Eqs. (2.10), (2.18), (2.25) and (2.26) we receive the coupled system Eqs. (2.28) to calculate the press parameter $\Pi_{C}$, the dimensionless temperature $\theta_{0}$ and finally from Eq. (2.29) the Reynolds number Re

$$
\begin{aligned}
& \frac{8 n}{\tilde{r}_{c}^{4}}=-\frac{\Pi_{C} \operatorname{Re}}{8 n m}-\left(\frac{\Pi_{C} \operatorname{Re}}{8 n m}-\frac{n G a}{4 \operatorname{Re}}\right) \frac{G r_{o}}{G a} \theta_{0} \\
& \Pi_{C}=\left(\frac{1}{\tilde{r}_{C}^{2}}-1\right)+\frac{6}{n \operatorname{Re}} \ln \frac{1}{\tilde{r}_{C}}, \\
& \theta_{0}=\tilde{\dot{q}}\left\{1-\exp \left[-\frac{B i}{4 n \operatorname{Re} \operatorname{Pr}}\left(1-\tilde{r}_{C}^{2}\right)\right]\right\} .
\end{aligned}
$$

Using the system equation (2.28), enables to calculate the Reynolds number from the equation

$$
f(\operatorname{Re})=-\frac{\Pi_{C} \operatorname{Re}}{8 n m}-\left(\frac{\Pi_{C} \operatorname{Re}}{8 n m}-\frac{n G a}{4 \operatorname{Re}}\right) \frac{G r_{o}}{G a} \theta_{0}-\frac{8 n}{\tilde{r}_{c}^{4}}=0 .
$$




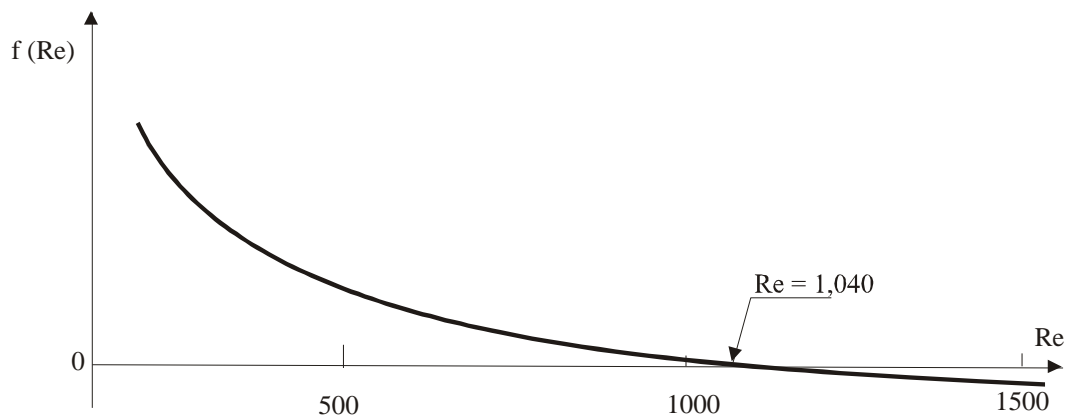

Fig. 5. Example dependence of the function $\mathrm{f}$ ( Re ) on the Reynolds number Re

The calculations were performed for the sample collector-chimney system. Figure 5 illustrates the method of determining the Reynolds number $\operatorname{Re}=1,040$. Next the dimensionless parameters $\Pi_{C}=402$ and $\theta_{0}=2.14$ were calculated. On that basis the dimensional parameters were also calculated, which can be seen in Tab.1 (Example 1).

Table 1. Table of theoretical results

\begin{tabular}{|c|c|c|c|c|c|c|c|}
\hline Example & $\dot{q}$ & $T_{o t}$ & $H_{C}$ & $R_{C}$ & $R$ & $h$ & $\operatorname{Re}$ \\
& $W / m^{2}$ & ${ }^{0} C$ & $m$ & $m$ & $m$ & $m$ & \\
\hline 1 & 800 & 25 & 20 & 0.50 & 50 & 0.1 & 1,040 \\
\hline 2 & 800 & 25 & 50 & 0.50 & 50 & 0.1 & 1,640 \\
\hline 3 & 900 & 25 & 50 & 0.50 & 50 & 0.1 & 1,660 \\
\hline
\end{tabular}

\begin{tabular}{|c|c|c|c|c|}
\hline \multirow{2}{*}{ Example } & $\begin{array}{c}u_{i n} \\
m / s\end{array}$ & $\begin{array}{c}\bar{u}_{C} \\
m / s\end{array}$ & $\begin{array}{c}p_{b}-p_{C 0} \\
P a\end{array}$ & $\begin{array}{c}T_{o} \\
{ }^{0} C\end{array}$ \\
\hline 1 & 0.16 & 12.92 & 188 & 124.62 \\
\hline 2 & 0.25 & 20.37 & 467 & 122.1 \\
\hline 3 & 0.26 & 20.62 & 478 & 134 \\
\hline
\end{tabular}

Next the dimensionless parameters $\Pi_{C}=402$ and $\theta_{0}=2.14$ were calculated.

On that basis the dimensional parameters were also calculated, which can be seen in table 1 (Example 1).

It is possible but more complicated to farther develop the theoretical design procedure to be used more accurately also for the turbulent flow of the air. In this case, the theoretical velocity distributions of the air flow in the collector channel (see Fig. 3 and Eqs. 2.4 and 2.5) and the pipe chimney should be changed. 


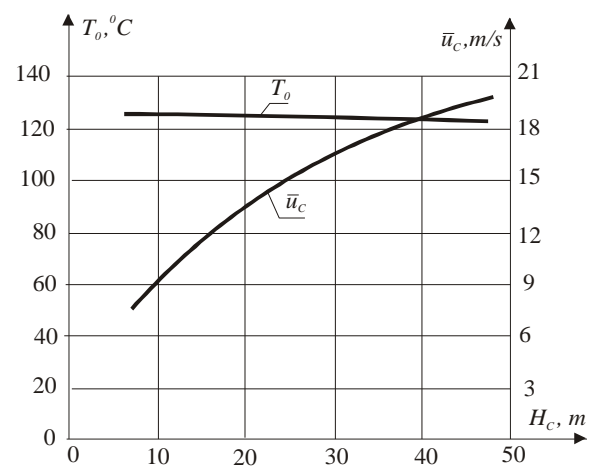

Fig. 6. The effect of height of the chimney on inside air temperature and velocity for $\mathrm{q}=800 \mathrm{~W} / \mathrm{m}^{2}$

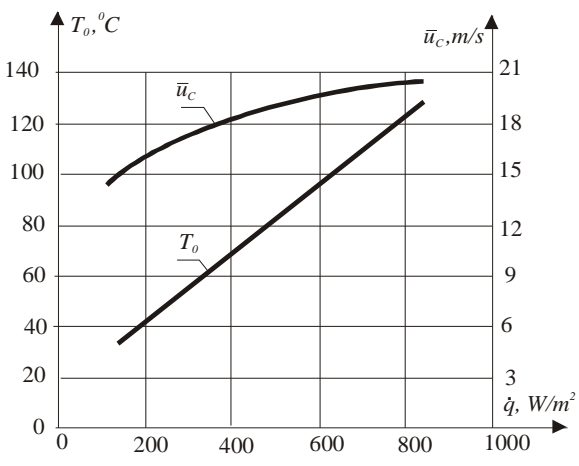

Fig. 7. The effect of heat flux density on air temperature and velocity in chimney for $\mathrm{H}_{\mathrm{c}}=50 \mathrm{~m}$

Figures 6. and 7. illustrate interrelationships between the height of chimney and the heat flux density and both the temperature and the velocity of the air inside the chimney. Increase of the chimney height leads to increase of inside air velocity and decrease of inside air temperature (Fig.6), whereas increasing heat flux density increase both the temperature and air velocity in the chimney (see Fig. 7).

\section{CONCLUSIONS}

In the paper the simple analytical method was developed which enables to evaluate most important characteristics of the collector - chimney system. The presented method is particularly suitable for laminar flow conditions in a collector (relatively small systems, not appropriate for electricity generation). For the turbulent flow conditions (larger systems with higher inside air velocities which can be used for small-scale electricity generation) the results are less accurate, although their accuracy still seems to be acceptable at least when first, approximate results are sufficient to be carried-out for the purpose of preliminary design evaluation of solar collector-chimney systems.

The above analysis on the demonstration collector-chimney system shows in the simple way that the heat can be converted to the motion of the air. It is confirmation of both the first and the second principle thermodynamics.

\section{NOMENCLATURE}

$R \quad$ radius of the collector, $m$;

$H_{c} \quad$ chimney height, $m$; 
$R_{c} \quad$ radius of the chimney, $m$;

$2 h$ collector height, $m$;

$n \quad$ ratio, $=h / R$;

$m \quad$ ratio, $=H_{C} / R$;

$z, r$ cylindrical coordinates, $m$;

$g$ gravitational acceleration, $m \mathrm{~s}^{-2}$;

$v \quad$ kinematic viscosity of air, $m^{2} s^{-1}$;

$\rho \quad$ density of the air, $\mathrm{kg} \mathrm{m}^{-3}$;

$c_{p} \quad$ specific heat at constant pressure of air, $J \mathrm{~kg}^{-1} \mathrm{~K}^{-1}$;

$\lambda \quad$ heat conductivity of air, $W m^{-1} K^{-1}$;

$\lambda_{s} \quad$ heat conductivity of the plate collector, $W m^{-1} K^{-1}$;

$\dot{m} \quad$ mass flow rate, $\mathrm{kg} \mathrm{s}^{-1}$;

$\dot{q} \quad$ heat flux density, $W m^{-2}$;

$\alpha \quad$ convection heat transfer coefficient, $W \mathrm{~m}^{-2} K^{-1}$;

$T_{o t}$ ambient temperature, ${ }^{\circ} \mathrm{C}$;

$T$ temperature of air in the collector, ${ }^{\circ} \mathrm{C}$;

$T_{0} \quad$ temperature of air in the chimney, ${ }^{\circ} \mathrm{C}$;

$u_{c} \quad$ velocity in the chimney, $m s^{-1}$;

$u_{i n} \quad$ velocity input to the collector, $m \mathrm{~s}^{-1}$;

$p$ pressure, $\mathrm{Pa}$;

$p_{b}$ barometric pressure, $\mathrm{Pa}$;

$p_{C 0}$ inlet pressure in the chimney, $\mathrm{Pa}$;

$\Pi$ dimensionless pressure;

$\theta \quad$ dimensionless temperature;

$B i$ Biot number;

$\mathrm{Ga}$ Galilei number;

$G r_{0}$ Grashof number;

Pr Prandtl number;

Re Reynolds number; 
$\tilde{u}_{c} \quad$ dimensionless velocity in the chimney;

$\tilde{r}_{c}$ dimensionless radius in the chimney;

$\tilde{r}$ dimensionless radius in the collector;

$\tilde{\dot{q}}$ dimensionless heat flux density.

\section{REFERENCES}

1. Asnaghi A, Ladjevardi S.M.: Solar chimney power plant performance in Iran. Renew Sustain Energy Rev, 16 2012, 3383-3390.

2. Baños R, Manzano-Agugliaro F, Montoya F.G, Gil C, Alcayde A.: Optimization methods applied to renewable and sustainable energy: a review. Renew Sustain Energy Rev, 15 2011, 1753-1766.

3. Bernardes MAdS, Weinrebe AVG.: Thermal and technical analyses of solar chimneys. Solar Energy, 2003; 511-524, 75.

4. Cabanyes I.: Proyecto de Motor Solar. La Energia Eléctrica - Revista General de Electricidad y sus Aplicaciones, 1903 61-65, 8.

5. Fluri T, Von Backström T.W.: Comparison of modelling approaches and layouts for solar chimney turbines. Sol Energy, 82 2008, 239-246.

6. Gannon AJ, Von Backström TW.: Controlling and maximizing solar chimney power output. In: Proceedings of the 1st international conference on heat transfer, fluid mechanics and thermodynamics, Kruger Park, South Africa; 2002.

7. Haaf W, Friedrich K, Mayr G, Schlaich J.: Solar Chimneys - Part I: Principle and Construction of the Pilot Plant in Manzanares, 1983, 3 - 20, Taylor \& Francis.

8. Hamdan M.O.: Analysis of solar chimney power plant utilizing chimney discrete model. Renew Energy, 56 2013, 50-54.

9. Maia CB, Ferreira AG, Valle RM, Cortez MFB. Theoretical evaluation of the influence of geometric parameter and materials on the behavior of the airflow in a solar chimney. Computers \& Fluids, 2009, 625-636,38.

10. Maia C.B, Castro J.O, Cabezas-Gómezb L, Hanriota S.M, Ferreirac A.G.: Energy and exergy analysis of the airflow inside a solar chimney. Renew Sustain Energy Rev, 27 2013, 350-361.

11. Park S.R, Pandey A.K, Tyagi V.V, Tyagi S.K.: Energy and exergy analysis of typical renewable energy systems. Renew Sustain Energy Rev, 30 2014, 105-123.

12. Sangi R.: Performance evaluation of solar chimney power plants in Iran Renew Sustain Energy Rev, 16 2012, 704-710. 
13. Schlaich J.: The Solar Chimney. Electricity from the Sun. Edition Axel Menges, Stuttgart, 1995.

14. Shi L, Chew M.Y.L.: A review on sustainable design of renewable energy systems. Renew Sustain Energy Rev, 16 2012, 192-207.

15. Tayebi T, Djezzar M.: Numerical Analysis of Flows in a Solar Chimney Power Plant with a Curved Junction. International Journal of Energy Science (IJES) Volume 3 Issue 4, 2013.

16. Zhai X.Q, Song Z.P, Wang R.Z.: A review for the applications of solar chimneys in buildings. Renew Sustain Energy Rev, 15 2011, 3757-3767.

17. Zhou X, Wang F, Ochieng R.M.: A review of solar chimney power technology. Renew Sustain Energy Rev, 14 201), 2315-2338.

\section{ANALIZA TEORETYCZNA PRZEPŁYWU MASY I ENERGII PRZEZ UKŁAD KOLEKTOR SŁONECZNY - KOMIN}

\section{Streszczenie}

Przepływ powietrza przez system kolektor słoneczny i komin, opisano w pracy stacjonarnymi równaniami zachowania: pędu (równanie Naviera-Stokesa), masy i energii, które następnie rozwiązano analitycznie przy spełnieniu warunków brzegowych: zanikanie prędkości powietrza na powierzchniach wewnętrznych tarcz kolektora i komina. Teoretyczna analiza pozwoliła uzyskać układ trzech uwikłanych nieliniowych analitycznych równań, które zapisano w postaciach bezwymiarowych. Liczbami bezwymiarowymi w rozwiązywanym problemie są dobrze znane w literaturze dotyczącej mechaniki płynów i termodynamiki liczby: Reynoldsa, Grashofa, Galileusza, Biota i Prandtla. W analizowanych równaniach występują też geometryczne parametry bezwymiarowe wyrażające stosunki podstawowych wymiarów geometrycznych systemu kolektor-komin: promień tarczy kolektora, szerokość szczeliny, wysokość i promień komina. W przedstawionym układzie równań liczba Reynoldsa traktowana jest jako liczba określana, co jest nowością stosowanej metody, a nie jak zazwyczaj bywa zadaną liczbą określającą zjawisko. Obliczanie jej dla danych warunków zewnętrznych i geometrycznych komina pozwala stosunkowo łatwo obliczyć pozostałe szukane wielkości jak prędkości powietrza wlotowego do kolektora i w kominie, rozkład temperatury powietrza w szczelinie i kominie. Otrzymane wielkości pozwalaja ostatecznie określić moc badanego systemu kolektor słoneczny-komin. Przedstawiona metoda obliczeniowa porządkuje dotychczasowy sposób projektowania kolektorów słonecznych i może być pomocna dla projektantów inżynierów energetyków.

Słowa kluczowe: układ kolektor słoneczny - komin, przepływ powietrza, analiza teoretyczna

Editor received the manuscript: 13.02.2017 